\title{
IMPLEMENTASI PENDIDIKAN KELUARGA DALAM UPAYA PENINGKATAN KARAKTER ANAK
}

\author{
Novrian Satria Perdana \\ Pusat Penelitian Kebijakan Pendidikan dan Kebudayaan, Kemendikbud \\ E-mail: novrian1711@gmail.com
}

\begin{abstract}
ABSTRAK
Saat ini terdapat peningkatan kasus anak berhadapan dengan hukum mencapai 1.434 kasus. Banyaknya kasus tersebut mengindikasikan gejala memudarnya karakter anak. Berdasarkan permasalahan tersebut, maka tujuan penelitian ini antara lain: 1) Menganalisis faktor-faktor yang berpengaruh dalam menerapkan pendidikan keluarga sebagai upaya peningkatan karakter anak, dan 2) Menganalisis strategi implementasi pendidikan keluarga dalam upaya peningkatan karakter anak sejak dini. Penelitian ini menggunakan pendekatan kuantitatif dan kualitatif, melalui wawancara dengan Dinas Pendidikan Kota Tangerang Selatan, Kepala Sekolah sampel, dan Orangtua. Sampel penelitian ini adalah 5 TK di Kota Tangerang Selatan, di Provinsi Banten. Hasil dari penelitian ini antara lain: 1) faktor-faktor yang berpengaruh: a) karakteristik orangtua, b) lingkungan, c) media elektronik/teknologi, d) ekonomi, dan e) dukungan Pemda kabupaten/kota terhadap program pendidikan keluarga, dan 2) Strategi implementasi antara lain: a) pelibatan orangtua dalam kegiatan kokurikuler, ekstrakurikuler, dan kegiatan lain untuk pengembangan diri anak di sekolah, b) penerapan lingkungan kehidupan sosial dan proses pembelajaran yang lebih rohani, c) komunikasi aktif antar ekosistem pendidikan, dan d) pelibatan seluruh elemen masyarakat dalam upaya peningkatan karakter anak.
\end{abstract}

Kata kunci: Pendidikan Keluarga, Karakter, Anak

\section{ABSTRACT}

At present there is an increase in cases of children facing the law reaching 1,434 cases. The number of these cases indicates the symptoms of waning children's character. Based on these problems, the objectives of this study include: 1) Analyzing the factors that influence the implementation of family education as an effort to improve the character of children, and 2) Analyze the strategy of implementing family education in an effort to improve the character of children early. This study uses a quantitative and qualitative approach, through interviews with the South Tangerang City Education Office, sample School Principals, and Parents. The research sample was 5 kindergartens in South Tangerang City, in Banten Province. The results of this study include: 1) factors that influence: a) parental characteristics, b) environment, c) electronic / technology media, d) economy, and e) district / city government support for family education programs, and 2 ) Implementation strategies include: a) parental involvement in cocurricular, extracurricular activities, and other activities for children's self-development in school, b) application of a more spiritual social life and learning process, c) active communication between educational ecosystems, and d) involvement of all elements of the community in an effort to improve children's character.

Keywords: Family Education, Character, Children

\section{PENDAHULUAN}

Pendidikan diperlukan sebagai upaya untuk menanamkan budi pekerti, memajukan pikiran serta memelihara jasmani anak. Lingkungan pendidikan yang pertama dan utama bagi seorang anak adalah keluarga, karena anak sejak pertama lahir bahkan saat masih di dalam kandungan telah memperoleh 
pendidikan

dari

orangtuanya

(khususnya ibu). Pendidikan dalam

keluarga lebih dahulu diperoleh anak sebelum ia mengenal lingkungan pendidikan lainnya. Pendidikan keluarga disebut sebagai pendidikan utama, karena di dalam lingkungan ini segenap potensi yang dimiliki anak terbentuk dan dikembangkan. William Bennett juga menyatakan bahwa keluarga merupakan wahana pertama dan utama bagi penanaman nilai-nilai karakter anak. Apabila keluarga gagal melakukan internalisasi nilai-nilai karakter pada anak, maka akan sulit bagi institusi-institusi di luar keluarga (termasuk sekolah) untuk memperbaikinya.

Keberadaan pendidikan keluarga dapat membentuk karakter manusia. Karakter manusia telah melekat pada kepribadian seseorang dan ditunjukkan dalam perilaku kehidupannya seharihari. Sejak lahir, manusia telah memiliki potensi karakter yang ditunjukkan oleh kemampuan kognitif dan sifat-sifat bawaannya. Karakter bawaan akan berkembang jika mendapat sentuhan pengalaman belajar dari lingkungannya. Keluarga merupakan lingkungan belajar pertama yang diperoleh anak dan akan menjadi fondasi yang kuat untuk membentuk karakter setelah dewasa. Hasil penelitian menunjukkan bahwa sekitar $50 \%$ variabilitas kecerdasan orang dewasa sudah terjadi ketika anak berusia empat tahun. Peningkatan $30 \%$ berikutnya terjadi pada usia delapan tahun, dan $20 \%$ sisanya pada pertengahan atau akhir dasawarsa kedua. Perkembangan kecerdasan diiringi oleh perkembangan mental kepribadian lainnya sampai usia remaja. Setelah dewasa, kecerdasan maupun perilaku kepribadian sudah relatif stabil, oleh sebab itu jika ingin membentuk kecerdasan dan karakter, waktu yang paling tepat adalah pada saat usia anakanak sampai dengan remaja.

Pendidikan karakter menjadi tanggung jawab bersama bagi semua pendidik, baik di rumah maupun di sekolah. Seiring berjalannya waktu berkembang fenomena karakter negatif anak. Fenomena karakter negatif anak yang dapat pula disebut sebagai kenakalan yang sering menjadi sumber berita di media masa antara lain adalah tindak kekerasan, tawuran, menyontek pada saat ujian dan sebagainya. Menurut Kartini Kartono dalam Puslitjakdikbud (2015), pada umumnya bentuk perilaku kenakalan seperti bolos sekolah, ugal-ugalan dijalan, seks pranikah sampai perbuatan yang menjurus pada perbuatan kriminal seperti pembunuhan, perampokan, penganiayaan, pemakaian obat-obatan terlarang dan perkelahian antar pelajar atau sekolah yang secara populer dikenal dengan istilah tawuran. Masalah kenakalan merupakan masalah yang kompleks terjadi di berbagai kota di Indonesia. Sejalan dengan arus globalisasi dan teknologi yang semakin berkembang, arus informasi yang semakin mudah diakses serta gaya hidup modernisasi, disamping memudahkan dalam mengetahui berbagai informasi di berbagai media, disisi lain juga membawa suatu dampak 
negatif yang cukup meluas di berbagai lapisan masyarakat. Menurut data yang dirilis oleh KPAI (2016), ada banyak macam bentuk kenakalan yang kini terjadi, seperti tertuang pada tabel 1 di bawah ini:

\section{Tabel 1. Kasus Kenakalan Anak}

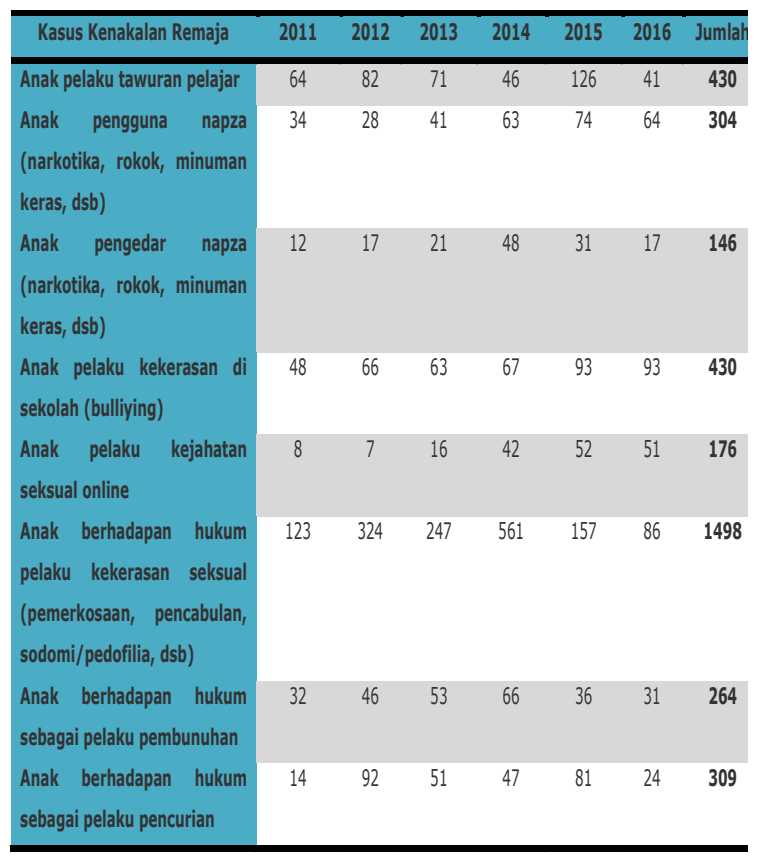

Sumber: Bank Data KPAI, 2017

Berdasarkan data pada tabel 1 di atas, jumlah kasus terbesar adalah pada pelaku tawuran dan kekerasan di sekolah, yaitu sebanyak 403 kasus. Sedangkan kasus yang sampai diproses hukum terbesar adalah kasus anak sebagai pelaku kekerasan seksual sebanyak 1498 kasus. Kasus menarik lainnya adalah semakin tingginya kasus anak pelaku kejahatan seksual online, yangmana pada tahun 2011 hanya 8 kasus terus meningkat hingga 51 kasus pada tahun 2016. Keberadaan teknologi yang semakin canggih ini dimanfaatkan secara negatif oleh sebagian kalangan anak-anak.
Beberapa kasus kenakalan yang sering terjadi dan selalu menelan korban adalah berupa tawuran. Contohnya adalah seperti yang terjadi di Pondok Aren, Tangsel pada bulan Desember 2018. Tawuran tersebut menyebabkan 1 orang tewas dan 3 luka bacok. Polisi menangkap 9 orang pelaku penganiayaan. Menurut Kapolres Tangerang Selatan (detik.com, 2018), sebagian besar kelompok remaja ini masih statusnya pelajar dan di bawah umur. Dari 9 yang sudah diamankan, dua orang dewasa dan tujuh masih di bawah umur, rata-rata masih sekolah di SMP dan SMK. Kasus serupa juga terjadi di tempat lainnya yaitu di kota Serang pada bulan Maret 2018. Seorang pelajar asal salahsatu sekolah tewas akibat senjata tajam (kompas, 2018).

Selain kasus tawuran, kasus kenakalan pelajar lainnya yang memanfaatkan keberadaan teknologi yaitu prostitusi online. Salahsatu kasusnya terjadi di Cimahi pada bulan Maret 2018, dengan modus yang bersangkutan itu bertindak sebagai mucikari dengan memberikan layanan prostitusi secara online melalui media sosial dan siap mengantar PSK yang masih dibawah umur kepada para pelanggannya yang berasal dari beberapa kalangan dan sudah mengetahui adanya kegiatan tersebut. Tersangka berinisial MR berusia 17 tahun yang telah duduk dibangku kelas 3 SMK, ditangkap atas adanya laporan masyarakat tentang praktek perdagangan anak dibawah umur yang dijual untuk dijadikan pekerja seks komersial (rri.co.id). 
Adanya peningkatan kenakalan anak merupakan wujud proses pendewasaan yang tidak tepat. Dalam proses menuju kedewasaan, anak membutuhkan penyesuaian sosial. Menurut Hurlock (1999), yang terpenting dan tersulit adalah penyesuaian diri dengan meningkatnya pengaruh teman sebaya, perkembangan teknologi, perubahan dalam perilaku sosial, penggelompokkan sosial yang baru, nilai-nilai baru dalam seleksi persahabatan, nilai-nilai baru dalam dukungan dan penolakan sosial.

Kita patut bertanya mengapa pendidikan banyak menghasilkan anak didik yang cerdas, pintar dan terampil, tapi belum banyak menghasilkan anak didik yang memiliki kepribadian yang sesuai dengan yang tujuan pendidikan nasional. Sehingga, bangsa kita mengalami krisis multidimensional. Untuk mengatasi permasalahan atau paling tidak dapat mengurangi masalah budaya dan karakter bangsa, dinilai paling tepat ialah melalui pendidikan. Pendidikan dianggap sebagai alternatif yang bersifat preventif karena pendidikan membangun generasi baru bangsa yang lebih baik, dan diharapkan dapat mengembangkan kualitas generasi muda yang akan datang. Pendidikan bermula dari keluarga, karena keluarga merupakan pusat pendidikan yang pertama dan terpenting.

\section{Pendidikan Keluarga}

Keluarga sebagai salah satu dari trisentra pendidikan adalah tempat pendidikan yang pertama dan utama. Interaksi di tahun-tahun awal dengan orang tua/ pengasuh serta kondisi lingkungan rumah memberikan pengaruh menetap dan jangka panjang pada kematangan perkembangan dan kesuksesan pendidikan anak. Sebagai elemen dalam ekosistem yang terdekat pada anak, orang tua/pengasuh di rumah mempunyai banyak keunggulan dan kesempatan untuk menjadi berdaya membentuk perilaku dirinya dan anaknya dalam sistem keluarga. Sistem keluarga yang kuat dan stabil akan memberikan pengaruh positif pada kecakapan hidup anak dan keterhubungan antarelemen sistem lain. Pola pengasuhan orang tua adalah hal yang perlu dipelajari secara terusmenerus, agar sensitif dan responsif pada tahap perkembangan anak dan keluarga. Proses pendidikan akan berhasil bila keseluruhan ekosistem di sekeliling anak bergerak selaras dan tidak saling menegasikan. Praktikpraktik pengasuhan sangat beragam dan dipengaruhi oleh budaya dan kondisi lingkungan keluarga. Layanan dan program pemerintah tidak melakukan penyeragaman, namun menyambut keberagaman budaya untuk memperkaya rujukan dan berkontribusi pada perbaikan. Pemerintah perlu melakukan lebih banyak intervensi khusus bagi masyarakat yang terpinggirkan, untuk memastikan seluruh masyarakat mendapat akses terhadap rujukan praktik-praktik baik pengasuhan. Salah satu tujuannya adalah sejak awal mencegah dan mempersempit kesenjangan kesempatan dan pencapaian antardaerah, antarstatus sosial ekonomi dan antarjenis kelamin. 
Pendidikan keluarga merupakan pendidikan yang berlangsung dalam keluarga yang dilaksanakan oleh orang tua sebagai tugas dan tanggung jawabnya mendidik anak dalam keluarga atau proses transformasi perilaku dan sikap di dalam kelompok atau unit sosial terkecil di masyarakat. Mansur (2015) mendefiniskan pendidikan keluarga adalah proses pemberian positif bagi tumbuh kembangnya anak sebagai pondasi pendidikan selanjutnya. Pendapat yang hampir sama juga dikemukakan Abdullah (2013) yang memberi pengertian pendidikan keluarga adalah segala usaha yang dilakukan oleh orang tua berupa pembiasaan dan improvisasi untuk membantu perkembangan pribadi anak.

Menurut Safrudin (2016), tujuan pendidikan keluarga diantaranya adalah memelihara dan melindungi anak sehingga dapat tumbuh dan berkembang dengan baik. Pelibatan orangtua dan kemitraaan satuan pendidikan dengan orangtua dalam menumbuhkembangkan karakter anak juga telah diterapkan di negara-negara lain, seperti di Jepang (melalui program Family Community dan Parent Advisory Committee) dan Amerika Serikat (berupa Parent Teacher Association).

Teori pendidikan keluarga yang dikemukakan oleh Ki-Hajar Dewantara dituangkan melalui "Tri Sentra Pendidikan" yang dikembangkan di Perguruan Taman Siswa, yaitu sentra keluarga, sentra perguruan dan sentra masyarakat. Dalam konteks sentra keluarta, pendidikan keluarga telah melahirkan konsep "among", dimana konsep among ini menuntut para orang tua untuk bersikap, yaitu: (a) ing ngarso sun tolodo, (b) ing madya mangun kasra, (c) tut wuri handayani. Dalam konteks sentra keluarga, Ki-Hajar Dewantara sangat peduli dalam memperhatikan, bahkan meminta para orang tua untuk mendidik anak-anak sejak usia dini (alam keluarga). Alam keluarga itu adalah suatu tempat yang sebaik-baiknya untuk melakukan pendidikan kesusilaan dan kesosialan, sehingga boleh dikatakan, bahwa keluarga itu tempat pendidikan yang lebih sempurna sifat dan wujudnya dari pada tempat-tempat lainnya, guna untuk melangsungkan pendidikan ke arah kecerdasan budi pekerti (pembentukan watak individual) dan sebagai persediaan hidup kemasyarakatan (KiHajar Dewantara, 1961 : 374). Pentingnya pendidkan keluarga bagi pertumbuhan dan perkembangan anak di kemukakan lebih lanjut oleh Ki-Hajar Dewantara (1961) bahwa alam keluarga, adalah: (a) alam pendidikan yang permulaan, pendidikan pertama kalinya bersifat pendidikan dari orang tua yang berkedudukan sebagai guru (penuntut), sebagai pengajar dan sebagai pemimpin, (b) di dalam keluarga itu anak-anak saling mendidik, (c) di dalam keluarga anak-anak berkesempatan mendidik diri sendiri, karena di dalam hidup keluarga itu mereka tidak berbeda kedudukannya, (d) didalam keluarga orang tua sebagai guru dan penuntun, sebagai pengajar, sebagai pemberi contoh dan teladan bagi anak-anak. Berdasarkan hal ini jelas bahwa karakteristik orangtua dapat 
menunjang keberhasilan penanaman pendidikan keluarga dalam upaya peningkatan karakter anak.

\section{Peningkatan Karakter Siswa}

Akar dari semua tindakan yang jahat dan buruk, tindakan kejahatan, terletak pada hilangnya karakter. Menurut Yaumi (2014), Karakter yang kuat adalah sandangan fundamental yang memberikan kemampuan kepada populasi manusia untuk hidup bersama dalam kedamaian serta membentuk dunia yang dipenuhi dengan kebaikan yang bebas dari kekerasan dan tindakan-tindakan yang tidak bermoral. Karakter yang kuat akan membentuk mental yang kuat. Sedangkan mental yang kuat akan melahirkan spirit yang kaut, pantang menyerah, dan sebagainya.

Peningkatan karakter diperlukan untuk membentuk karakter yang kuat. Peningkatan karakter merupakan segala upaya/kegiatan yang bertujuan untuk meningkatkan akhlak, budi pekerti yang mengacu pada nilai-nilai dan kebijakan yang diterapkan dalam kehidupan sehari-hari di lingkungan sekolah, keluarga dan masyarakat yang mencakup karakter religius, jujur, toleransi, disiplin, kerja keras, kreatif, mandiri, demokratis, rasa ingin tahu, semangat kebangsaan, cinta tanah air, menghargai prestasi, bersahabat atau komunikatif, cinta damai, gemar membaca, peduli lingkungan, peduli sosial dan tanggungjawab.

Ketika karakter anak sudah meningkat, maka anak akan mudah memiliki kemampuan berfikir kritis yang dapat bermanfaat untuk peningkatan kualitas pribadinya. Menurut Saroinsong (2018), kemampuan berpikir kritis mencakup: (1) Kemampuan mengidentifikasi asumsi yang diberikan; (2) Kemampuan merumuskan pokok-pokok permasalahan; (3) Kemampuan menentukan akibat dari suatu ketentuan yang diambil; (4) Kemampuan mendeteksi adanya bias berdasarkan pada sudut pandang yang berbeda; (5) Kemampuan mengungkap data/definisi/teorema dalam menyelesaikan masalah;

Kemampuan mengevaluasi argumen yang relevan dalam penyelesaian suatu masalah.

Penerapan karekter kepada anak, khususnya anak usia dini diperlukan upaya yang berkesinambungan. Menurut Suriadi (2018) dalam penelitiannya, penerapan pembiasaan atau budaya sekolah dilakukan melalui proses menyelami karekter dan mengenalkan diri dengan anak karena setiap anak karakternya dan psikologisnya serta kognitifnya berbeda-beda. Penelitian ini menyimpulkan bahwa di dalam faktorfaktor yang mempengaruhi karakter anak di sekolah antara lain bentuk kasih sayang dan perhatian orangtua di dalam keluarga. Keteladan guru, kasih sayang guru, pergaulan teman dan guru dilingkungan sekolah. Dan sikap pergaulan di dalam lingkungan masyarakat.

Selanjutnya berdasarkan penelitian yang dilakukan oleh 
Sukiyani (2014) menunjukkan bahwa keberhasilan peningkatan karakter anak dipengaruhi oleh faktor karakteristik orangtua, ekonomi, dan harapan orang tua pada anaknya. Orang tua mendidikkan karakter melalui pengasuhan yang baik, mencontohkan perilaku dan pembiasaan, pemberian penjelasan atas tindakan, penerapan standar yang tinggi dan realistis bagi anak, dan melibatkan anak dalam pengambilan keputusan. Selain itu, kondisi sosial ekonomi keluarga juga memiliki peran penting dalam pola pikir orang tua dalam menerapkan pola asuh/pendidikan bagi anak-anaknya dalam upaya peningkatan karakter anak-anaknya.

Penelitian berikutnya tentang "Hubungan Lingkungan Sekolah, Keluarga, Dan Masyarakat Terhadap Karakter Siswa SMK Negeri Kelompok Teknologi Se-Kabupaten Sleman" oleh Indriatno (2012). Hasil penelitian ini menunjukkan bahwa: (1) terdapat hubungan yang positif dan signifikan antara lingkungan sekolah dengan karakter siswa SMKN kelompok teknologi di Kabupaten Sleman ( $\mathrm{p}<$ 0,05); (2) terdapat hubungan yang positif dan signifikan antara lingkungan keluarga dengan karakter siswa SMKN kelompok teknologi di Kabupaten Sleman ( $\mathrm{p}<0,05)$; (3) terdapat hubungan yang positif dan signifikan antara lingkungan masyarakat dengan karakter siswa SMK Negeri kelompok teknologi di Kabupaten Sleman ( $\mathrm{p}$ < 0,05); (4) terdapat hubungan yang positif dan signifikan antara lingkungan sekolah, keluarga, dan masyarakat dengan karakter siswa SMK Negeri kelompok teknologi di Kabupaten Sleman $(\mathrm{p}<0,05)$. Ketiga ubahan bebas dapat menjelaskan $14,2 \%$ terhadap ubahan terikatnya.

Berdasarkan uraian di atas, telah dibahas mengenai pentinganya penerapan pendidikan keluarga dalam upaya peningkatan karakter anak. Namun berdasarkan penelitian terdahulu ditemukan ada beberapa faktor yang dapat menunjang keberhasilan penerapan pendidikan keluarga dalam kaitannya dengan peningkatan karakter anak. Oleh karena itu, tujuan penelitian ini antara lain:

1) Menganalisis faktor-faktor yang berpengaruh dalam upaya peningkatan karakter anak, dan

2) Menganalisis strategi implementasi pendidikan keluarga dalam upaya peningkatan karakter anak.

\section{METODE}

Ada dua model analisis untuk menjawab dua tujuan penelitian ini. Untuk menjawab tujuan penelitian yang pertama tentang analisis faktor-faktor yang berpengaruh dalam menerapkan pendidikan keluarga sebagai upaya peningkatan karakter anak, menggunakan analisis kuantitatif melalui regresi, kemudian untuk menjawab tujuan pertanyaan penelitian yang kedua tentang analisis strategi implementasi pendidikan keluarga dalam upaya peningkatan karakter anak, menggunakan analisis kualitatif berdasarkan hasil diskusi dengan Dinas Dinas Pendidikan Kota, Kepala Sekolah 
sampel, siswa dan Orangtua Siswa. Sampel penelitian ini adalah $5 \mathrm{TK}$ di Kota Tangerang Selatan, di Provinsi Banten.

Jenis data untuk menjawab tujuan pertama yang digunakan adalah data interval dengan menggunakan Metode Successive Interval. Teknik skala pengukuran dengan menggunakan skala Likert. Pernyataan diberikan berjenjang dengan 5 (lima) kategori respons yaitu (1=sangat tidak setuju, 2=tidak setuju, $3=$ kurang setuju, 4=setuju, dan $5=$ sangat setuju). Sedangkan sumber data yang digunakan adalah data primer. Data diperoleh melalui kuesioner yang disebarkan kepada orangtua siswa dan siswa (dibimbing pengisiannya). Penarikan sampel hanya mengambil 1/3 berdasarkan metode penarikan sampel acak sederhana (simple random sampling). Perhitungan statistik dalam penelitian ini menggunakan program SPSS 21. Variable dependen dalam penelitian ini adalah implementasi pendidikan keluarga dan untuk variabel independen penelitian ini antara lain: a) karakteristik orangtua, b) lingkungan, c) media elektronik, d) ekonomi, dan e) dukungan Pemda.

Model analisis regresi linear berganda yang digunakan untuk menguji hipotesis adalah sebagai berikut:

$$
\begin{gathered}
\mathrm{Y}=\mathrm{b}_{0}+\beta_{1} \mathrm{X}_{1}+\boldsymbol{\beta}_{2} \mathrm{X}_{2}+\beta_{3} \mathrm{X}_{3}+\beta_{4} \mathrm{X}_{4} \\
+\beta_{5} \mathrm{X}_{5}+\varepsilon \mathrm{t}
\end{gathered}
$$

$\mathrm{b}_{0}=$ Konstanta

$\beta_{1}$ sampai $\beta_{5}=$ Koefisien regresi untuk $\mathrm{X}_{1}$ sampai $\mathrm{X}_{5}$ $\varepsilon=$ Standard Error

Y= Implementasi Pendidikan Keluarga

$\mathrm{X}_{1}=$ Karakteristik Orangtua

$\mathrm{X}_{2}=$ Lingkungan

$\mathrm{X}_{3}=$ Media elektronik

$\mathrm{X}_{4}=$ Ekonomi

$\mathrm{X}_{5}=$ Dukungan Pemda

Uji Validitas dan Reliabilitas. Uji validitas atau kesahihan atau derajat ketepatan mengukur sejauh mana ketepatan dan kecermatan alat ukur dalam melakukan fungsi ukurnya. Reliabilitas adalah ukuran yang menunjukkan seberapa tinggi suatu instrument dapat dipercaya atau dapat diandalkan, artinya reliabilitas menyangkut ketepatan (konsisten) alat ukur.

\section{Uji Asumsi Klasik: a) Uji} Normalitas bertujuan untuk mengetahui apakah distribusi sebuah data mengikuti atau mendekati distribusi normal, b) Uji Multikolinearitas, menguji apakah model regresi ditemukan adanya korelasi antar variabel bebas. c) Uji Heteroskedastisitas, untuk menguji dalam sebuah model regresi apakah terjadi ketidaksamaan varian dari residual suatu pengamatan ke pengamatan lain. Analisis Regresi Linear Berganda Analisis regresi linear berganda diuji menggunakan program SPSS versi 21. Variabel Pembagian kuesioner secara random kepada konsumen, dimana keseluruhan variabel dalam penelitian ini diukur dengan model skala likert. Skala ini digunakan 
untuk mengukur sikap, pendapat, dan persepsi seseorang atau sekelompok orang tentang fenomena sosial. Dengan skala likert, maka variabel yang diukur dapat dijabarkan menjadi indikator variabel. Kemudian indikator tersebut dijadikan berupa pernyataan atau pertanyaan.

\section{HASIL DAN PEMBAHASAN}

Metode analisis data yang digunakan dalam penelitian ini adalah analisis regresi berganda yaitu persamaan regresi yang melibatkan 2 (dua) variabel atau lebih. Regresi berganda digunakan untuk mengetahui besarnya pengaruh perubahan dari suatu variabel independen terhadap variabel dependen. Dalam pengolahan data yang didapatkan proses penghitungan regresi menggunakan bantuan program SPSS versi 21.

\section{Uji Penyimpangan Asumsi Klasik}

a) Uji Normalitas

Berdasarkan hasil pengolahan data maka didapatkan hasil bahwa semua data berdistribusi secara normal dan tidak terjadi penyimpangan, sehingga data yang dikumpulkan dapat diproses dengan metode-metode selanjutnya. Hal ini dapat dibuktikan dengan memperhatikan sebaran data yang menyebar disekitar garis diagonal pada "Normal P-Plot of Regresion Standardized Residual" sehingga dapat dikatakan bahwa model regresi dalam penelitian ini berdistribusi normal.

b) Uji Multikolinieritas

Uji multikolinieritas dilakukan untuk menguji apakah pada model regresi ditemukan adanya korelasi antar variabel independen. Jika terjadi korelasi, maka dinamakan terdapat problem Multikolinieritas. Model regresi yang baik seharusnya tidak terjadi korelasi diantara variabel independen. Dari perhitungan menggunakan program SPSS versi 21 dapat kita ketahui bahwa nilai VIF dan tolerance sebagai berikut : 1). Variabel Karakteristik Orangtua mempunyai nilai VIF sebesar 1,006 dan tolerance sebesar 0,994; 2). Variabel Lingkungan mempunyai nilai VIF sebesar 1,493 dan tolerance sebesar 0,$670 ; 3)$. Variabel Media Elektronik mempunyai nilai VIF sebesar 1,658 dan tolerance sebesar 0,603 ; 4). Variabel Ekonomi mempunyai nilai VIF sebesar 1,228 dan tolerance sebesar 0,$411 ; 5)$. Variabel Dukungan Pemda mempunyai nilai VIF sebesar 1,342 dan tolerance sebesar 0,343 . Dari ketentuan yang ada bahwa jika nilai VIF < 10 dan tolerance $>0,10$ maka tidak terjadi gejala multikolinearitas dan nilai- nilai yang didapat dari perhitungan adalah sesuai dengan ketetapan nilai VIF dan tolerance, sehingga dapat disimpulkan bahwa dalam model regresi tersebut tidak menunjukkan adanya gejala multikolinearitas.

c) Uji Hetersokedastisitas

Uji heteroskedastisitas bertujuan untuk menguji apakah dalam model regresi terjadi ketidaksamaan varians dari residual satu pengamatan ke pengamatan yang lain. Jika varians dari residual satu pengamatan ke pengamatan yang lain tetap maka disebut Homokedastisitas dan jika 
berbeda disebut Heteroskedastisitas. Berdasarkan hasil perhitungan tidak membentuk pola tertentu atau menyebar secara acak jadi kita dapat menyimpulkan bahwa data tersebut tidak menunjukkan adanya gejala heteroskedastisitas.

\section{d) Uji Autokorelasi}

Bertujuan untuk menguji apakah dalam model regresi terdapat korelasi diantara kesalahan pengganggu dalam periode tertentu. Untuk melakukan uji autokorelasi, pada penelitian ini menggunakan besaran Durbin Watson. Perhitungan menghasilkan nilai Durbin Watson sebesar 1,876 dan nilai tersebut terletak di antara $-2<$ DW $\leq 2$ yaitu $-2<$ $1,776 \leq 2$ maka model ini tidak mengandung gejala autokolerasi.

\section{Analisa Regresi}

Dari hasil pengolahan menggunakan program SPSS versi 21 didapat persamaan sebagai berikut:

$$
\begin{gathered}
Y=1,328+0,296 X_{1}+0,371 X_{2}+ \\
0,249 X_{3}+0,136 X_{4}+0,105 X_{5}
\end{gathered}
$$

Dari persamaan regresi berganda diatas dapat kita ketahui bahwa :

a) Konstanta 1,324 mengandung arti apabila variabel Karakteristik orangtua, lingkungan, media elektronik, ekonomi, dukungan Pemda tidak ada $\left(\mathrm{X}_{1}, \mathrm{X}_{2}, \mathrm{X}_{3}, \mathrm{X}_{4}\right.$, dan $X_{5}=0$ ), maka keberhasilan Implementasi Pendidikan Keluarga berada pada angka 1,328

b) Koefisien dari variabel karakteristik orangtua dalam persamaan regresi berganda bernilai positif adalah 0,296 , hal ini menunjukkan bahwa setiap kenaikan 1 poin untuk karakteristik orangtua maka akan meningkatkan keberhasilan implementasi pendidikan keluarga sebesar 0,296\%.

c) Koefisien dari variabel lingkungan dalam persamaan regsesi berganda bernilai positif sebesar 0,371 , hal ini menunjukkan bahwa setiap kenaikan $1 \%$ untuk lingkungan (semakin baik lingkungan) maka akan meningkatkan keberhasilan implementasi pendidikan keluarga sebesar 0,371\%.

d) Koefisien dari variabel media elektronik dalam persamaan regresi berganda bernilai positif sebesar 0,249 hal ini menunjukkan bahwa setiap kenaikan $1 \%$ untuk media elektronik (pemanfaatan media elektronik yang efektif) maka akan meningkatkan keberhasilan implementasi pendidikan keluarga sebesar 0,249\%.

e) Koefisien dari variabel ekonomi dalam persamaan regresi berganda bernilai positif sebesar 0,136 hal ini menunjukkan bahwa setiap kenaikan $1 \%$ untuk ekonomi (semakin baik kondisi ekonomi orangtua) maka akan meningkatkan keberhasilan implementasi pendidikan keluarga sebesar $0,136 \%$.

f) Koefisien dari variabel dukungan Pemda dalam persamaan regresi berganda bernilai positif sebesar 0,105 hal ini menunjukkan bahwa setiap kenaikan $1 \%$ untuk dukungan Pemda (berupa program kegiatan implementasi pendidikan 
keluarga) maka akan meningkatkan keberhasilan implementasi pendidikan keluarga sebesar $0,105 \%$.

\section{Pengujian Hipotesis}

Dengan perhitungan menggunakan program SPSS versi 21 diperoleh hasil bahwa tidak ada pengaruh yang positif dan signifikan antara variabel bebas yang terdiri dari karakteristik orangtua, lingkungan, media elektronik, ekonomi, dan dukungan pemda terhadap variabel terikat yaitu implementasi pendidikan keluarga. Dengan demikian maka Ho ditolak dan Ha diterima, sehingga hipotesis yang menyatakan ada pengaruh yang positif dan signifikan antara masing-masing variable bebas dengan variabel terikatnya.

\section{Uji F}

Uji $F$ digunakan untuk menguji keberartian semua variabel bebas (karakteristik orangtua, lingkungan, media elektronik, ekonomi, dan dukungan pemda) secara bersama-sama terhadap variabel terikat (implementasi pendidikan keluarga (Y)). Berdasarkan hasil perhitungan SPSS versi 21 diperoleh nilai $\mathrm{F}$ hitung $=157,748$ dengan signifikansi $\mathrm{F}$ sebesar 0,000 . Maka F hitung > F tabel, atau signifikansi $F$ sebesar $\quad 0,000$ menunjukkan lebih kecil dari 0,05. Dengan demikian Ho ditolak dan $\mathrm{Ha}$ diterima, sehingga hipotesis yang menyatakan ada pengaruh yang positif dan signifikan antara variable bebas secara bersama-sama terhadap variabel terikat dapat diterima.

\section{Koefisien Determinasi $\left(\mathbf{R}^{2}\right)$}

Persentase pengaruh semua variabel independen terhadap variabel dependen ditunjukkan oleh besarnya Koefisien Determinasi $\left(\mathrm{R}^{2}\right)$. Koefisien Determinasi $\left(\mathrm{R}^{2}\right)$ ini menunjukkan seberapa besar pengaruh variabel bebas terhadap variabel dependent atau bebas yang dinyatakan dalam persen (\%) (Gujarati, 1997). Variabel independen dapat dijelaskan oleh variabel dependen sebesar $83,7 \%$ sedangkan sisanya $16,3 \%$ diterangkan oleh faktor yang lain. Penelitian ini telah sesuai dengan kerangka teori dari Ki Hadjar Dewantara dan beberapa hasil penelitian terdahulu yang menyimpulkan bahwa faktor karakteristik orangtua, lingkungan, media elektronik, ekonomi, dan dukungan pemda berpengaruh positif terhadap keberhasilan implementasi pendidikan keluarga dalam upaya peningkatan karakter anak.

Selanjutnya setelah diketahui faktorfaktor yang mempengaruhi keberhasilan implementasi pendidikan keluarga dalam upaya peningkatan karakter anak, maka dilakukan diskusi mendalam bersama beberapa narasumber untuk menyusun beberapa strategi dalam implementasi pendidikan keluarga. Program Pendidikan Keluarga berperan dalam memberdayakan satuan pendidikan untuk melakukan kemitraan dengan orang tua serta meningkatkan kesadaran orang tua agar peduli dan terlibat dalam memajukan pendidikan anak-anak mereka bekerjasama dengan satuan pendidikan dan masyarakat pegiat pendidikan. Dengan demikian, 
tercapai keharmonisan antara keluarga, sekolah, dan masyarakat. Selain itu, program pendidikan keluarga juga diarahkan pada penumbuhan karakter yaitu kegiatan pembiasaan sikap dan perilaku positif di sekolah yang dimulai dari PAUD sampai ke jenjang SMA/SMK serta pendidikan nonformal.

Undang-undang sistem pendidikan nasional nomor 20 Tahun 2003, Bab I Pasal 1 ayat 13 , menyebutkan bahwa "pendidikan informal adalah jalur pendidikan keluarga dan lingkungan." Selanjutnya pasal-pasal 27 ayat 1, mempertegas bahwa 'kegiatan pendidikan informal yang dilakukan oleh keluarga dan lingkungan berbentuk kegiatan belajar secara mandiri”.

Berdasarkan Undang-undang di atas, secara konstitusional keberadaan jalur pendidikan secara informal atau disebut juga dengan jalur pendidikan di dalam keluarga menjadi kekuatan hukum yang legal formal. Secara hakhak kewarganegaraan sudah seharusnya dilaksanakan oleh semua orang tua. Apalagi ketentuan-ketentuan secara teknis operasionalisasi memiliki ketetapan yuridis formal. Namun dalam prakteknya, pendidikan keluarga ternyata belum sepenuhnya diterapkan oleh orang tua yang memiliki anak-anak dirumah.

Banyak faktor mengapa konsep pendidikan di dalam keluarga yang seharusnya telah diberikan oleh orang tua, belum sepenuhnya dipraktekan dalam kehidupan keseharian orang tua dalam mendidik anak-anaknya di rumah. Menurut hasil diskusi, faktor penyebab itu semua adalah :

1) Kurangnya pengetahuan, pemahaman para orang tua tentang kedudukan peran dan fungsi serta tanggung jawab para orang tua dalam hal pendidikan anak-anak di rumah. Kurangnya pengetahuan dan pemahaman bisa disebabkan tingkat pendidikan para orang tua yang rendah, akibat ketidakmampuan dalam penyelesaian sekolah.

2) Lemahnya peran sosial budaya masyarakat dalam membangun kesadaran akan pentingnya pendidikan keluarga. Keluarga sering kali mengabaikan nilai-nilai edukasi didalam lingkup rumah tangga, membiarkan anakanak bermain dan bergaul tanpa kontrol yang memadai (efektif), kurangnya perhatian tatkala ia sedang berkomunikasi dengan sesamanya.

3) Kuatnya desakan dan tarikan pergulatan ekonomi para orang tua dalam memenuhi tuntutan dan kebutuhan keluarga. Sehingga mengabaikan peran-peran sebagai fungsi dan tugas orang tua bahkan ada yang tanpa disadari, akibat tuntutan kebutuhan ekonomi mereka (ayah-ibu) lupa akan tanggung jawabnya sebagai orang tua. Mereka tinggalkan anak-anak tanpa perhatian, bimbingan dan pendidikan sebagaimana mestinya.

4) Kemajuan arus teknologi informasi yang mengglobal turut pula mempengaruhi cara berfikir dan bertindak para orang tua. Misalnya perilaku instant dengan memberi 
fasilitas media yang tidak mendidik, membiarkan mengakses berbagai informasi yang tidak mendidik melalui tayangan media televisi dan pengawasan (proteksi) yang tidak terkontrol akibat ketidakpedulian para orang tua.

Hasil diskusi ini sejalan dengan penelitian yang pernah dilakukan oleh Rudiyanto,dkk (2018) yang menyatakan bahwa peran orang tua dan pendidik dalam melakukan pengasuhan adalah untuk membantu anak untuk memahami potensi yang dimilikinya dan pengasuhan tersebut dilakukan dengan membuat keputusan untuk lebih responsif, konsisten dan menjalin interaksi yang baik dengan anak.

Selanjutnya berdasarkan hasil diskusi mendalam bersama beberapa narasumber, maka dirumuskan beberapa strategi implementasi pendidikan keluarga dalam upaya peningkatan karakter anak antara lain: a) pelibatan orangtua dalam kegiatan kokurikuler, ekstrakurikuler, dan kegiatan lain untuk pengembangan diri anak di sekolah, b) penerapan lingkungan kehidupan sosial dan proses pembelajaran yang lebih rohani, c) komunikasi aktif antar ekosistem pendidikan, dan d) pelibatan seluruh elemen masyarakat dalam upaya peningkatan karakter anak.

\section{SIMPULAN}

Berdasarkan hasil analisis regresi dan diskusi mendalam bersama beberapa narasumber terkait, maka kesimpulan dari penelitian ini antara lain:
1. Karakteristik orangtua, lingkungan, media elektronik, ekonomi, dan dukungan Pemda memiliki pengaruh positif dan signifikan terhadap keberhasilan implementasi pendidikan keluarga dalam upaya peningkatan karakter anak di Provinsi Banten

Untuk meningkatkan keberhasilan implementasi pendidikan keluarga dalam upaya peningkatan karakter anak diperlukan proses integrasi dari sekolah, orangtua, dan Pemda. Adapun beberapa strategi yang dapat dilakukan antara lain: a) pelibatan orangtua dalam kegiatan kokurikuler, ekstrakurikuler, dan kegiatan lain untuk pengembangan diri anak di sekolah, b) penerapan lingkungan kehidupan sosial dan proses pembelajaran yang lebih rohani, c) komunikasi aktif antar ekosistem pendidikan, dan d) pelibatan seluruh elemen masyarakat dalam upaya peningkatan karakter anak.

\section{DAFTAR PUSTAKA}

Abdullah, M. Imron. 2013. Pendidikan Keluarga Bagi Anak, Cirebon : Lektur.

Al Tridhonanto dan Beranda Agency. 2014. Mengembangkan Pola Asuh Demokratis. Jakarta: Elex Media Komputindo

Djamarah, Syaiful Bahri. 2014. Pola Asuh Orangtua dan Komunikasi dalam Keluarga. Jakarta: Rineka Cipta

Elizabeth, B Hurlock. 1999. Perkembangan Anak. Jakarta: Erlangga.

Heru, Kurniawan. 2016. Sekolah Kreatif: Sekolah Kehidupan yang Menyenangkan untuk Anak. Yogyakarta: Ar Ruzz Media 
Indriatno, Galeh Nur. 2012. Hubungan Lingkungan Sekolah,

Keluarga, Dan Masyarakat Terhadap Karakter Siswa SMK Negeri Kelompok Teknologi Se-Kabupaten Sleman. Program Studi Pendidikan Teknik Sipil Dan Perencanaan Fakultas Teknik Universitas Negeri Yogyakarta

KPAI. 2016. Data kasus kenakalan anak. Dirilis melalui website www.kpai.go.id

Ki Hajar Dewantara. 1961. Ilmu Pendidikan, Yogyakarta : Taman Siswa.

Puslitjakdikbud. 2015. Isu Aktual: Kajian Tindak Kekerasan Siswa. Balitbang Kemendikbud Rudiyanto, dkk. 2018. After School Care: Alternatif Layanan Pendidikan Dan Pengasuhan Bagi Anak Usia 6-8 Tahun. Jurnal Pendidikan : Early Childhood, Vol. 2 No. 2a, November 2018 halaman 1-11

Safrudin, Aziz. 2016. Pendidikan Keluarga: Konsep dan Strategi. Yogyakarta: Gaya Media

Saroinsong, Wulan Patria. 2018. Penerapan Model Pembelajaran Berbasis Proyek Untuk Meningkatkan Keterampilan Berpikir Kritis Dan Kreatif Mahasiswa. FIP Universitas Negeri Malang: Jurnal Pendidikan Anak Usia Dini, Vol 1, No 1, 2018, halaman 66 - 72

Sukiyani, Fita, dkk. 2014. Pendidikan Karakter dalam Lingkungan Keluarga. Jurnal Socia, Mei 2014 Vol. 11, No. 1 57-70

Suriadi, 2018. Urgensi Manajemen Sekolah Dalam Membentuk Karakter Anak. Jurnal Pendidikan : Early Childhood
Vol. 2 No. 2a, November 2018 halaman 1-12

Undang-Undang Nomor 20 Tahun 2003 tentang Sistem Pendidikan Nasional

Undang-Undang Republik Indonesia Nomor 35 Tahun 2014 Tentang Perubahan Atas Undang-Undang Nomor 23 Tahun $2002 \quad$ Tentang Perlindungan Anak

Yaumi, Muhammad. 2014. "Pendidikan Karakter: Landasan. Pilar. Dan Implementasi". Jakarta: Prenadamedia Group 